\title{
correspondence
}

\section{The NPT and the IAEA}

SIR,-Y Your editorial on "The unloved treaty" (March 13, 1975) shows how important it is to exercise the utmost care in reaching conclusions about political as well as scientific matters. The gist of the article is that the foundations of the Non-Proliferation Treaty (NPT) "show signs of crumbling" and that it has failed "to catch on".

It is strange to read this at a time when all the non-nuclear-weapon countries of the EEC are at the point of completing the process of ratification of the treaty, when the Government of Japan is reported to be putting the treaty to the Diet in April for discussion and ratification and indeed when many countries are seriously concerned to prevent further nuclear proliferation and to increase the effectiveness of IAEA safeguards. During the past year we have witnessed several steps taken by the main supplier countries in this direction, such as an agreement on a list of nuclear equipment and materials which will "trigger" the application of safeguards requirements for safeguards on specialised technological information and an increased interest in safeguards in countries that have previously been somewhat indifferent.

The editorial's comments on the peaceful uses of nuclear explosions are, I believe, equally inaccurate. Article V of the NPT specifies that the petential benefits of peaceful applications of nuclear explosions be made available to non-nuclear-weapon states party to the treaty "under appropriate international observation and through appropriate international procedures." And further, "n on-nuclear-weapon states party to the treaty shall be able to obtain such benefits, pursuant to a special international agreement or agreements, through an appropriate international body with adequate representation of non-nuclear-wea pon states".

When you ask "so where is the international body?" you overlook that the IAEA, with 106 member states, would clearly seem to meet the requirements set out in NPT and that there is no need to establish a new international organisation. In 1968, the United Nations Conference of nonnuclear-weapon states recommended that the agency initiates studies on its possible functions in the field of peaceful nuclear explosions (PNF), and the agency's suitability in this respect has been specifically recognised by its own General Conference and by the United Nations' General Assembly.

Some of the major steps taken by the IAEA with respect to the responsibilities outlined in Article $\mathrm{V}$ are:

- In 1972, guidelines for "The international observation of PNE under the provisions of NPT and analogous provisions in other international agreements" were developed and approved by the agency's Board of Governors.

- In 1974, an advisory group developed "Procedures for the Agency to Use in Responding to Requests for PNE-Related Services". These procedures have also been approved by the Board of Governors.

- The Agency has convened a series of technical meetings which reviewed the "state-of-the-art". These meetings were convened in 1970, 1971, 1972 and in January 1975.

- Potential PNE Supplier States were approached in December 1974 concerning their participation in elaborating the basic conditions to be incorporated into the special agreements referred to in Article V of NPT.

- A separate "Unit for Peaceful Nuclear Explosions Services" was established within the IAEA Secretariat in January 1975.

Far from resisting "the accumulation of yet more duties for a secretariat already fully extended", the IAEA has taken active steps to meet its obligations as the appropriate international body mentioned in Article $\mathrm{V}$ of the NPT. The point that is entirely missed in your editorial is that despite the extensive exchange of information that the IAEA has promoted over several years on this subiect (incidentally we do not put out "fairly enthusiastic publicity" but merely publicise the statements of national experts), the equally extensive preparatory work that the IAEA has done on the legal and administrative aspects, not a single formal request for a PNE has yet been received by us. We have had a few enquiries from member states, and we have arranged some preliminary investigations, but in no case has a serious project emerged.

Finally, your conclusion that someone should have the courage at the NPT Review Conference to suggest that "the treaty be scrapped and new approaches tried" is most difficult to take seriously. The NPT and the related Test Ban Treaty are the two major achievements of post-war arms control negatiations. What is needed is to pursue efforts to control the spread of nuclear weapons and to strengthen and supplement NPT by additional non-proliferation nuclear arms control and disarmament measures. Yours faithfully,

SigVard EKLUND

International Atomic Energy Agency, Vienna

\section{Cabora Bassa hazards}

Sir,-The Cabora Bassa Dam, the second barrage across the Zambezi, closed on December 5, 1974. The 171metres high dam, situated on the Cabora Bassa rapids (the natural boundary between the Middle and Lower Zambezi), will hold back a $250 \mathrm{~km}$ long lake, with a mean breadth of $11 \mathrm{~km}$ and a maximum capacity of $6.23 \times 10^{10}$ cubic metres at a retention level of $336 \mathrm{~m}$ AMSL. It will inundate 2,739 square $\mathrm{km}$ with a mean depth of $25.2 \mathrm{~m}$ (maximum depth $157 \mathrm{~m}$ ). Five south bank turbines at present nearing completion each have a power capacity of $430 \mathrm{MW}$. Four more turbines planned for a future north bank station will bring the eventual power capacity to $3,870 \mathrm{MW}$.

Pre-impoundment surveys of the status of the Zambezi and some of its major tributaries in relation to the dam, began in April 1973 and included physico-chemical characteristics of the rivers (A. Hall, I. Valente and J. da Costa Martins), phytoplankton (J. C. Oliveira), fish (R. Morais), zooplankton and benthos (the author). The objective has been to provide basic data from which to monitor future changes in the valley ecosystem, occurring directly or indirectly as a result of the dam. The work has also produced the first information on the Zambezi since Kariba was closed in 1958, and has shown the effect of the combined influence of the Kariba and Kafue dams on the river in Moçambique.

In January 1974, a small team studied the probable future impact of the dam on the valley, including such problems as aquatic macrophyte infestation (expected to include Salvinia molesta $\mathrm{D}$. S. Mitchell, Pistia stratiotes L. and Eichhornia crassipes Mart.), fisheries development, lake management, the creation of national parks and reserves and the impact of the dam on agriculture, industrial development and existing game reserves and fisheries in the Lower Zambezi Valley. During the study, the valley planning authority 
engineers, Gabinete do Plano do Zambezi (GPZ) in Tete revealed that they intended to fill the lake to capacity during a period of four months, allowing less than 60 cubic metres of water to discharge daily to the gorge below the dam. In normal years, the average flow through the gorge is of the order of 2,000-3,000 cubic metres per second.

Recommendations made by the team to the GPZ and the then Portuguese and Mocambique governments included allowance of a minimum discharge from the dam during the filling phase of 400-500 cubic metres per second with the lake taking between one to two years to reach maximum capacity, thus reducing the expected detrimental effects associated with prolonged water reduction in the Lower Zambezi. The gorge below the dam, approximately $25 \mathrm{~km}$ long (river depth between 30 $40 \mathrm{~m}$ ), has no source of water other than the dam. Four major rivers enter the Zambezi between the gorge and the coast, $560 \mathrm{~km}$ downstream, namely the Luia, Revuboé, Mazoe (Luenha) and Shire, the Shire draining Lake Malawi to the north. Unpublished data supplied by the GPZ shows that these rivers add little by way of volume (though the Shire considerably alters the chemistry of the Zambezi below their confluence) and then only during the latter part of the wet season (mid-January to late March).

Accompanying a press announcement of closure (Noticias de Mocambique, 28.11.74) was the comment that the dam would be completely closed until such time as the water level reached $306.2 \mathrm{~m}$ AMSL (approximately three weeks after closure according to the report), after which time water would be discharged into the gorge. The lake would then fill at a slower rate. The minimum discharge recommendations were ignored. The engineers anticipated that little or nu noticeable difference in river level would occur during this early filling phase due to the expected onset of the rains. This statement contradicts the river flow data supplied by the GPZ and gives no consideration to the possible long-term ecological consequences of such action. To compound the problem, local rains did not begin until two to three weeks after closure. Within seven days of closure, the river at Tete (approximately $120 \mathrm{~km}$ downstream from Cabora Bassa) was reported to have dropped to dry season levels. By February 8 this year, levels had dropped sufficiently to prevent operation of water supply intakes for Tete, and no discharge from the dam had taken place up to this date. At the same time, large numbers of spawning fish were stranded in the lower river and slaughtered in large numbers by local Africans.

This apparent disregard of recom- mendations made with long-term considerations in mind bodes ill for future co-operation between ecologist and engineer and could have important long-term repercussions for the agriculture (mainly sugar cane), fisheries and game reserves of the Lower Zambezi Valley and its floodplains. Important decisions, such as the timing of artificial floods and the controlled fluctuation of water level in order to facilitate development of hydrophytes, essential for fisheries development in the new lake, must be taken in the near future. A dialogue between ecologist and engineer is essential if a balanced use of the resource is to be made.

Bryan R. Davies

Institute for Freshwater Studies,

Rhodes University, Grahamstown.

Cape Province, South Africa

\section{African finds}

SIR,-In his article on the Leakeys' work at East Rudolf (Nature, February $20,1975)$ Bernard Wood writes, of the Taung discovery in 1924: "It was fortunate that the remains of a fossil monkey had been recognised at the same quarry only a few months previously." In fact, fossil baboons were found at Taung as early as 1920 . On 19th May 1920 , a paper on seven or eight fossil baboons from Taung was read in Cape Town before the Royal Society of South Africa by S. H. Haughton, subsequently Director of the Geological Survey of the Union of South Africa, and still later, Honorary Director of the Bernard Price Institute for Palaeontological Research at the University of the Witwatersrand. Haughton's paper of 1920 was not published in full, though he made his notes available to $R$. A. Dart, R. Broom and J. H. S. Gear. An abstract of Haughton's communication was published in 1925. To accommodate the small baboon skulls from Taung, he had proposed to create a new species, Papio antiquus. However, as his paper was not published and as no type was designated, the name $P$. antiquus was both a nomen dubium and a nomen non rite publicatum. Gear recognised that the sample of cercopithecoids from Taung included two different species to which he gave the names, $P$. africanus and $P$. izodi.

Presumably, the "fossil monkey" referred to by Wood was a baboon cranium which, in 1924, one of Dart's students, Josephine Salmons, recovered from the home of E. G. Izod, a director of the Northern Lime Company. This find led Dart to request R. B. Young, then professor of geology at the Witwatersrand University and about to survey the Taung area, to speak to the Timeworks manager in the hope of obtaining more specimens.
The recovery of the Taung australopithecine skull, said by Wood to have been discovered by accident, actually occurred as follows: $\mathrm{Mr}$ M. de Bruyn, a miner at Taung, had been interested for many years in collecting fossilized bones. A week before Professor Young's visit, in October 1924, de Bruyn had blasted out a number of fossils. These included the brain cast of a baboon and, embedded in another fragment of breccia, a second, larger endocast; among the other rock fragments part of a lower jaw was exposed. The manager, A. E. Spiers, and de Bruyn showed the collection to Young, who selected certain pieces which Spiers railed to Dart. It was the second, larger endocast which turned out to be that of Australopithecus. Another piece of rock made a perfect join with the former and from it Dart extracted the face. (There is no evidence whatever to support Bernard Wood's statement that "The child's skull was in fact identified ... by Professor Young": indeed this would have been virtually impossible since most of the skull was totally embedded in the matrix. Only a part of the endocast was showing on the surface of one piece and the back of the lower jaw on another piece. Identification was out of the question until Dart had extracted the specimen from its matrix in time for Christmas, 1924.)

The article also stated that Taung was situated "in what was then Bechuanaland". This common mistake arose because Taung was situated in the northernmosit part of the Cape Province, an area formerly known as 'British Bechuanaland' (and totally distinct from 'Bechuanaland'). But this are was in 1924 an integral part of the Union of South Africa, entirely separate from the Bechuanaland Protectorate which is today the Republic of Botswana. This old name of the northern Cape Province led several scientists and textbook writers erroneously to place Taung in 'Bechuanaland' or even 'Botswana'.

Wood's statement that ' $\ldots$ work has been resumed recently at three of these sites' (in the Transvaal) is misleading, since Brain resumed excavation at Swartkrans in 1965, while Tobias and Hughes began excavating at Sterkfontein in 1966 . Work has continued ever since, in the case of Sterkfontein without any interruption for 48 weeks a year for over eight years. Hence, although the article admirably reflects recent work in East Africa, it does scant justice to the palaeo-anthropological researches in the Transvaal over the past decade.

Phillip V. Tobias

Department of Anatomy,

University of the Witwatersrand,

Johannesburg 2001, South Africa 